\title{
Maggot secretions suppress pro-inflammatory responses of human monocytes through elevation of cyclic AMP
}

\author{
M. J. A. van der Plas • M. Baldry • J. T. van Dissel • \\ G. N. Jukema • P. H. Nibbering
}

Received: 2 February 2009 / Accepted: 2 June 2009/Published online: 3 July 2009

(C) The Author(s) 2009. This article is published with open access at Springerlink.com

\begin{abstract}
Aims/hypothesis Maggots of the blowfly Lucilia sericata are used for the treatment of chronic wounds. As monocytes may contribute to the excessive inflammatory responses in such wounds, this study focussed on the effects of maggot secretions on the pro-inflammatory activities of these cells. Methods Freshly isolated monocytes were incubated with a range of secretions for $1 \mathrm{~h}$ and then stimulated with lipopolysaccharides (range $0-100 \mathrm{ng} / \mathrm{ml}$ ) or lipoteichoic acid (range $0-5 \mu \mathrm{g} / \mathrm{ml}$ ) for $18 \mathrm{~h}$. The expression of cell surface molecules, cytokine and chemokine levels in culture supernatants, cell viability, chemotaxis, and phagocytosis and killing of Staphylococcus aureus were measured.

Results Maggot secretions dose-dependently inhibited production of the pro-inflammatory cytokines TNF- $\alpha$, IL$12 \mathrm{p} 40$ and macrophage migration inhibitory factor by lipopolysaccharides- and lipoteichoic acid-stimulated monocytes, while enhancing production of the antiinflammatory cytokine IL-10. Expression of cell surface receptors involved in pathogen recognition remained unaffected by secretions. In addition, maggot secretions altered the chemokine profile of monocytes by downregulating macro-
\end{abstract}

M. J. A. van der Plas • M. Baldry • J. T. van Dissel •

P. H. Nibbering $(\bowtie)$

Department of Infectious Diseases, C5-P,

Leiden University Medical Center (LUMC),

Albinusdreef 2, PO Box 9600, 2300 RC Leiden, the Netherlands

e-mail: p.h.nibbering@lumc.nl

M. J. A. van der Plas

Department of Surgery, Leiden University Medical Center,

Leiden, the Netherlands

G. N. Jukema

Department of Trauma Surgery, Free University Medical Center, Amsterdam, the Netherlands phage inflammatory protein-1 $\beta$ and upregulating monocyte chemoattractant protein-1 and IL-8. Nevertheless, chemotactic responses of monocytes were inhibited by secretions. Furthermore, maggot secretions did not affect phagocytosis and intracellular killing of $S$. aureus by human monocytes. Finally, secretions induced a transient rise in the intracellular cyclic AMP concentration in monocytes and Rp-cyclic AMPS inhibited the effects of secretions.

Conclusions/interpretation Maggot secretions inhibit the pro-inflammatory responses of human monocytes through a cyclic AMP-dependent mechanism. Regulation of the inflammatory processes by maggots contributes to their beneficial effects on chronic wounds.

Keywords Chemokines - Chemotaxis - Chronic wounds . Cyclic AMP - Cytokines - Inflammation · Phagocytosis .

Signal transduction

$\begin{array}{ll}\text { Abbreviations } \\ \text { cAMP } & \text { Cyclic AMP } \\ \text { fMLP } & \text { Formyl-Met-Leu-Phe } \\ \text { HBSS } & \text { Hanks' buffered salt solution } \\ \text { MCP } & \text { Monocyte chemoattractant protein } \\ \text { MIF } & \text { Macrophage migration inhibitory factor } \\ \text { MIP } & \text { Macrophage inflammatory protein } \\ \text { RANTES } & \begin{array}{l}\text { Regulated on activation, normal T cell } \\ \text { expressed and secreted }\end{array} \\ \text { TLR } & \text { Toll-like receptor }\end{array}$

\section{Introduction}

Chronic wounds are common in patients with vascular insufficiencies and underlying chronic conditions such as 
diabetes mellitus, as well as patients suffering from acute, extended trauma [1]. Up to $15 \%$ of the more than 200 million diabetes patients worldwide develop a foot ulcer at some stage, leading to over one million amputations every year [2]. The importance of chronic wounds in the pathway to lower limb amputation is paramount, as $84 \%$ of amputations are preceded by a diabetic foot ulcer [3]. Chronic wounds and amputations in persons with diabetes often result in decreased physical, emotional and social function of patients, a reduced quality of life and major economic costs for both the patients, their families and society $[4,5]$.

Sterile larvae (maggots) of the blowfly Lucilia sericata are used for the treatment of different types of wounds including diabetic foot ulcers [6-9]. The success rate of this therapy is around $68 \%$ for wounds unresponsive to conventional therapies, although some characteristics (chronic limb ischaemia, wound depth and age) may negatively influence the outcome [8]. Besides the removal of necrotised tissue and infectious microorganisms, maggots may promote fibroblast migration and tissue remodelling [10]. Moreover, maggot secretions potently inhibit the pro-inflammatory responses of human neutrophils without affecting their antimicrobial activities [11]. Another prominent type of phagocyte in wounds is the monocyte. In response to chemotactic substances these cells migrate from the blood into the infected tissue to combat invading microorganisms. In addition, monocytes regulate the inflammatory process by secreting cytokines and growth factors, thereby recruiting more inflammatory cells as well as by antigen processing/presentation and lymphocyte activation.

In contrast to acute wound healing, chronic wounds are marked by a prolonged and dysregulated inflammatory phase. Inflammatory cells like neutrophils, monocytes and macrophages are not only present in excess numbers [12-14], they also have enhanced production and release of pro-inflammatory cytokines, proteases and reactive oxygen species, leading to growth factor inactivation and tissue destruction [15]. Therefore, inhibition of the pro-inflammatory responses of these cells could restrict their deleterious effects and thus contribute to healing processes. To obtain more insight into the mechanisms underlying the beneficial effects of medicinal maggots, this study focussed on the effects of maggot excretions and/or secretions on the pro-inflammatory activities of human monocytes.

\section{Methods}

Maggots and their excretions/secretions Sterile second- and third-instar larvae of L. sericata were a kind gift from
BioMonde (Barsbüttel, Germany). Maggot excretions/ secretions were collected as previously described [11]. Next, maggots were incubated for $1 \mathrm{~h}$ in $\mathrm{H}_{2} \mathrm{O}$ to remove their excretions, washed and then their secretions were collected as described for excretions/secretions. In the assays excretions/secretions and secretions alone were tested simultaneously.

Isolation of human monocytes Peripheral blood mononuclear cells from healthy donors were isolated from buffy coats by Ficoll amidotrizoate $(\rho=1.077 \mathrm{~g} / \mathrm{ml})$ density centrifugation at $700 \times \mathrm{g}$ for $20 \mathrm{~min}$. Cells from the interphase were washed three times and monocytes were purified using anti-CD14-coated Microbeads (Miltenyi Biotec, Bergisch Gladbach, Germany). When testing antimicrobial activities, cells in the interphase were used to avoid possible functional impairment of the monocytes by the interaction of CD14 with anti-CD14 coated microbeads. For the chemotaxis assay lymphocytes were removed from the interphase using anti-CD3 microbeads (Miltenyi) to avoid obstruction of the filters by large numbers of these cells.

Stimulation of monocytes Approximately $1 \times 10^{6}$ monocytes $/ \mathrm{ml}$ of RPMI-1640 supplemented with $2 \mathrm{mmol} /$ 1 glutamax-I/glutamine, $2 \mathrm{mmol} / 1 \mathrm{penicillin} / \mathrm{streptomycin}$ and $10 \%$ (vol./vol.) inactivated fetal calf serum (standard medium) were transferred to wells of a 24-well plate and incubated with excretions/secretions and secretions alone or, as a control, $\mathrm{H}_{2} \mathrm{O}$ for $1 \mathrm{~h}$ followed by stimulation with lipopolysaccharides (Sigma Chemical Co., St Louis, MO, USA), lipoteichoic acid (Invivogen, Toulouse, France) or no stimulus. After 18 to $22 \mathrm{~h}$ of incubation at $37^{\circ} \mathrm{C}$ and $5 \% \mathrm{CO}_{2}$, supernatant fractions were collected and stored at $-70^{\circ} \mathrm{C}$.

Measurement of cytokine and chemokine levels The cytokine and chemokine levels in the supernatant fractions of cell cultures were assessed using kits (BioSource CytoSet; Biosource Europe, Nivelles, Belgium; and Bio-Plex; BIORAD, Hercules, CA, USA).

Chemotaxis Migration of monocytes was measured as previously described [11] with the following modifications. The lower compartments contained a mixture (vol./vol.) of $25 \%$ HEPES buffer and $75 \%$ supernatants from monocyte cultures stimulated as described above. To test direct effects of excretions/secretions and secretions alone on monocyte migration, $10 \mathrm{nmol} / \mathrm{l}$ formyl-Met-Leu-Phe (fMLP) (Sigma) was added as well. In the upper compartment, $50 \mu 1$ of $2 \times$ $10^{6}$ monocytes $/ \mathrm{ml}$ of RPMI-1640 were placed. Results are expressed as the number of cells counted in $2 \mu \mathrm{m}^{2}$ areas in 11 subsequent levels within each filter. 
Phagocytosis assay Staphylococcus aureus Strain 42D of $S$. aureus were grown overnight in tryptone soya broth at $37^{\circ} \mathrm{C}$ while shaking, then washed and resuspended $(1 \times$ $10^{7} / \mathrm{ml}$ ) in Hanks' buffered salt solution (HBSS) $0.1 \%$ (vol./wt) gelatine. Equal volumes of this suspension and a monocyte suspension $\left(1 \times 10^{7} / \mathrm{ml}\right.$ of $\mathrm{HBSS}-0.1 \%$ gelatine $)$ that had been freshly isolated or incubated for $18 \mathrm{~h}$ in excretions/secretions or secretions alone were mixed and $10 \%$ (vol./vol.) AB-serum was added. Subsequently, $100 \mu \mathrm{l}$ of this mixture were transferred to hydron-coated surface plates (Nunclon; Nalge Nunc International, Rochester, NY, USA) containing excretions/secretions, secretions alone or $\mathrm{H}_{2} \mathrm{O}$. At various intervals after incubation at $37^{\circ} \mathrm{C}$ while shaking, cells and bacteria were collected in cold HBSS and centrifuged at $140 \times g$ for $6 \mathrm{~min}$. Next, the number of non-cell-associated bacteria was determined microbiologically using serial dilutions plated on to agar plates. Phagocytosis is expressed as the percentage decrease of non-cell-associated $S$. aureus.

Intracellular killing assay Opsonisation and intracellular killing of $S$. aureus were done as previously described [16] using hydron-coated plates (Nalge Nunc). Disruption of monocytes was performed by collecting these cells in $\mathrm{H}_{2} \mathrm{O}$ supplemented with $0.01 \%$ (vol./wt) BSA and then vortexing these suspensions for $60 \mathrm{~s}$. Killing is expressed as the percentage decrease in the number of viable bacteria determined as described above.

Flow cytometry Cells were incubated with FITC- or phycoerythrin-conjugated monoclonal antibodies directed against CD11b, CD14, CD32, CD35, CD54 and CD64
(BD Pharmingen; BD BioSciences, Erembodegem, Belgium), and against CD16 (EuroBioSciences, Friesoythe, Germany), CD282 (Toll-like receptor [TLR]-2) and CD284 (TLR-4; Hycult Biotechnology, Uden, the Netherlands for both); incubation was in PBS containing $0.5 \%$ (wt/vol.) BSA for $30 \mathrm{~min}$ on ice. Analyses were performed on FACSCalibur (Becton Dickinson, La Jolla, CA, USA) in combination with CellQuest Pro 4.0.2 software.

Cell viability Monocytes were stimulated and incubated as described above and then incubated with fluorescencelabelled Annexin V $(2.5 \mu \mathrm{g} / \mathrm{ml}$; Sigma $)$ and propidium iodide $(1 \mu \mathrm{g} / \mathrm{ml}$; Sigma) in $10 \mathrm{mmol} / \mathrm{l}$ HEPES (pH7.4) as previously described [17]. The mean fluorescence intensities of the cells were analysed by flow cytometry.

Measurement of intracellular cyclic AMP concentration Monocytes in RPMI were incubated with a range of excretions/secretions, secretions alone or no stimulus for various intervals up to $2 \mathrm{~min}$. The reaction was stopped by adding lysis buffer. Next, the cyclic AMP (cAMP) content of these samples was measured using an enzyme immunoassay system (cAMP Biotrak; Amersham Biosciences Benelux, Roosendaal, the Netherlands). The cAMP concentrations were calculated from these values and the mean cell volume of human monocytes [18].

Inhibition of cAMP-dependent protein kinase $A$ Monocytes were pre-incubated for $45 \mathrm{~min}$ with the protein kinase A inhibitor adenosine-3',5'-cyclic monophosphorothioate, triethyl ammonium salt (Rp-cAMPS; $1 \mathrm{mmol} / \mathrm{l}$; BioLog Life Science Institute, Bremen, Germany), followed by $1 \mathrm{~h}$

Table 1 Effect of maggot secretions on lipopolysaccharide-induced production of various cytokines and chemokines by monocytes

\begin{tabular}{|c|c|c|c|c|c|c|}
\hline \multirow[t]{2}{*}{ Cytokine/chemokine } & \multicolumn{2}{|l|}{ Control cells } & \multicolumn{4}{|c|}{ Per cent induction by maggot secretions } \\
\hline & Median (ng/ml) & Range (ng/ml) & $0.35 \mu \mathrm{g} / \mathrm{ml}$ & $3.5 \mu \mathrm{g} / \mathrm{ml}$ & $35 \mu \mathrm{g} / \mathrm{ml}$ & $70 \mu \mathrm{g} / \mathrm{ml}$ \\
\hline IL-1 $\beta$ & 0.5 & $0.2-1.6$ & $97 \pm 4$ & $81 \pm 11$ & $80 \pm 10$ & $91 \pm 16$ \\
\hline IL-6 & 25 & $13-40$ & $89 \pm 7$ & $95 \pm 4$ & $92 \pm 11$ & $116 \pm 15$ \\
\hline IL-8 & 153 & $81-310$ & $120 \pm 7 *$ & $121 \pm 9 *$ & $149 \pm 15^{*}$ & $268 \pm 63 *$ \\
\hline IL-10 & 0.4 & $0.05-2.1$ & $108 \pm 8$ & $142 \pm 11^{\dagger}$ & $206 \pm 35^{\dagger}$ & $209 \pm 35^{\dagger}$ \\
\hline IL-12p40 & 0.3 & $0.1-5.4$ & $98 \pm 6$ & $82 \pm 6^{*}$ & $42 \pm 7^{\dagger}$ & $39 \pm 10^{\dagger}$ \\
\hline TNF- $\alpha$ & 11 & $5-25$ & $109 \pm 14$ & $84 \pm 5^{*}$ & $29 \pm 5^{*}$ & $19 \pm 4^{*}$ \\
\hline MIF & 0.08 & $0.04-0.2$ & $85 \pm 21$ & $41 \pm 14^{\dagger}$ & $13 \pm 5^{\dagger}$ & $5 \pm 3^{\dagger}$ \\
\hline MCP-1 & 37 & $12-68$ & $119 \pm 8$ & $134 \pm 17$ & $250 \pm 33^{\dagger}$ & $367 \pm 66^{\dagger}$ \\
\hline MIP-1 $\beta$ & 20 & $1-155$ & $107 \pm 11$ & $104 \pm 20$ & $23 \pm 9^{\dagger}$ & $17 \pm 7 *$ \\
\hline RANTES & 0.4 & $0.2-1.5$ & $101 \pm 3$ & $109 \pm 6$ & $103 \pm 10$ & $74 \pm 14$ \\
\hline
\end{tabular}

The results of the control cells, shown as median value and range, are set at $100 \%$, with the effect of secretions expressed as a percentage of these values

The results are means \pm SEM of six to ten experiments

${ }^{*} p<0.05,{ }^{\dagger} p<0.005$ for difference from control monocytes stimulated with lipopolysaccharides 


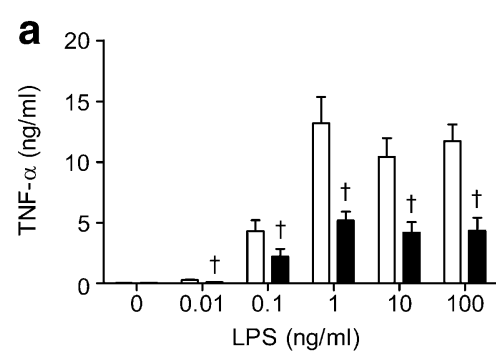

Fig. 1 Effect of maggot secretions $(35 \mu \mathrm{g} / \mathrm{ml})$ on the production of TNF- $\alpha$ (a), IL-12p40 (b) and IL-10 (c) by monocytes challenged with a range of lipopolysaccharide concentrations as indicated (log-scale).

incubation with excretions/secretions, secretions alone or $\mathrm{H}_{2} \mathrm{O}$ and stimulation for 18 to $22 \mathrm{~h}$ with $100 \mathrm{ng}$ of lipopolysaccharides $/ \mathrm{ml}$. Thereafter, cytokine production was measured.

Statistical analysis Differences between the values for cells incubated with excretions/secretions or secretions alone and those for cells incubated with $\mathrm{H}_{2} \mathrm{O}$ were analysed with a Wilcoxon test using Graphpad Prism version 4.02.

\section{Results}

Effect of secretions on monocyte cytokine and chemokine production The results revealed that secretions decreased lipopolysaccharides-induced production of the proinflammatory cytokines TNF- $\alpha$, IL-12p40 and macrophage migration inhibitory factor (MIF) by monocytes in a dose-dependent manner without effecting IL- $1 \beta$ or IL-6 (Table 1). Production of the anti-inflammatory cytokine IL-10 was increased by secretions. Secretions also inhibited lipopolysaccharides-induced production of the chemokine macrophage inflammatory protein (MIP)- $1 \beta$ by monocytes and increased monocyte chemoattractant protein (MCP)-1 and IL-8, but had no effect on RANTES (regulated on activation, normal $\mathrm{T}$ cell expressed and secreted). Secretions did not affect baseline levels of
IL-1 $\beta$, IL-6, IL-10, IL-12p40, TNF- $\alpha$, RANTES or MIP$1 \beta$ (data not shown). In contrast, $70 \mu \mathrm{g}$ of secretions $/ \mathrm{ml}$ increased production of MCP-1 by naive monocytes from 15 (range: 3-53) to 1,049 (range: $425-9,063$ ) pg/ml and that of IL-8 from 578 (range: 136-1,436) to 3,236 (range: $1,879-5,934) \mathrm{pg} / \mathrm{ml}$, while decreasing production of MIF from 72 (range: 19-318) pg/ml to below the detection limit $(10 \mathrm{pg} / \mathrm{ml})$ when using 35 or $70 \mu \mathrm{g}$ of secretions $/ \mathrm{ml}(n=6-8)$.

To determine whether the effective components are secreted or excreted by maggots, we compared the effects of secretions alone pools to excretions/secretions pools from the same maggots on the cytokine and chemokine profile of monocytes. The results showed that secretions alone had better effects than excretions/secretions when using equal protein concentrations (data not shown). However, the protein concentration was $30 \pm 2 \%$ lower for secretions alone than for excretions/secretions pools, meaning that we used the products of more maggots when testing secretions alone. Therefore, we tested the differences in effects when using the volume of the secretions alone pools necessary to obtain $35 \mu \mathrm{g}$ for example, and used the same volume for testing the excretions/secretions pools (which was $50 \mu \mathrm{g}$ ). The results showed that effects of secretions alone and of excretions/secretions were equal, indicating that the active component is secreted by maggots. Therefore, we combined the results for secretions alone and excretions/secretions and referred to them as secretions.
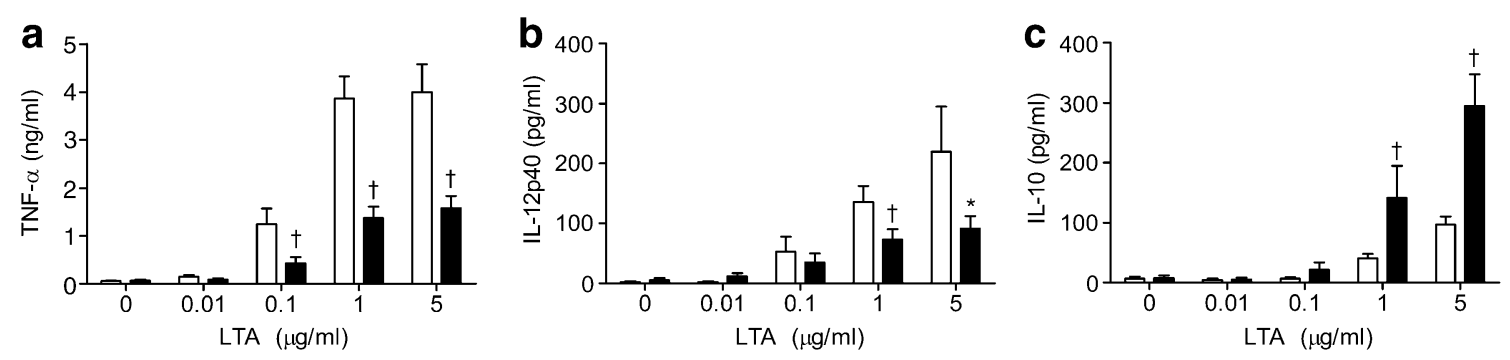

Fig. 2 Effect of maggot secretions $(35 \mu \mathrm{g} / \mathrm{ml})$ on the production of TNF- $\alpha(\mathbf{a})$, IL-12p40 (b) and IL-10 (c) by monocytes challenged with a range of lipoteichoic acid concentrations as indicated (log-scale).
The results are means and SEM of ten experiments. ${ }^{*} p<0.05$ and ${ }^{\dagger} p<$ 0.005 for difference from control-incubated monocytes stimulated with lipoteichoic acid 


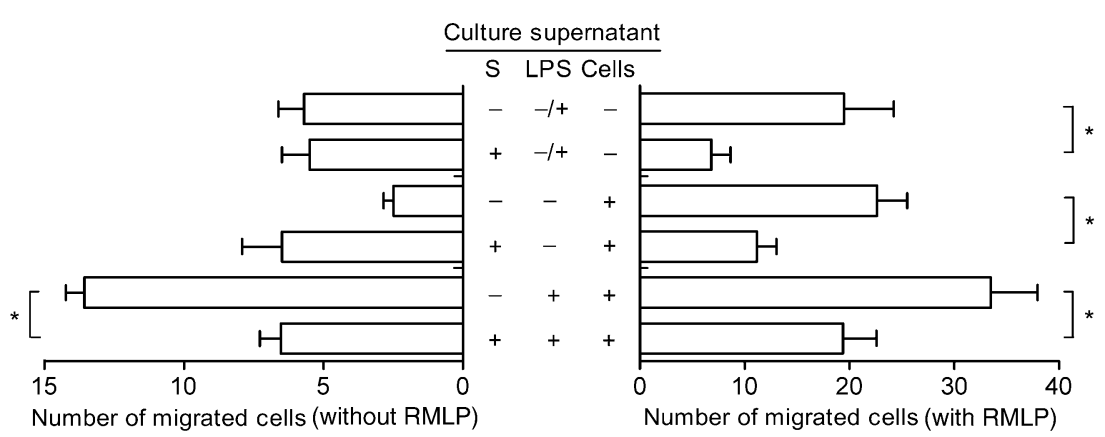

Fig. 3 Effect of maggot secretions on the chemotactic activity of monocytes. Migration of monocytes in response to chemokines in cell-culture supernatants without or with $10 \mathrm{nmol} / \mathrm{l} \mathrm{fMLP}$ as indicated was monitored using a Boyden microchemotaxis chamber. Results are

Effect of secretions on the sensitivity of monocytes to lipopolysaccharides and lipoteichoic acid The results revealed that the production of TNF- $\alpha$ by monocytes was downregulated significantly by $35 \mu \mathrm{g}$ of secretions $/ \mathrm{ml}$ for all concentrations of lipopolysaccharides (Fig. 1a). Production of IL-12p40 by monocytes was dose-dependently inhibited by secretions (Fig. 1b), while production of IL-10 by monocytes was enhanced (Fig. 1c). In addition, secretions $(35 \mu \mathrm{g} / \mathrm{ml})$ dose-dependently reduced the production of TNF- $\alpha$ (Fig. 2a) and IL-12p40 (Fig. 2b) by monocytes in response to lipoteichoic acid, while enhancing IL-10 (Fig. 2c).

Effect of culture supernatants of secretions-treated monocytes on cell migration Since incubation of monocytes with secretions altered production of several chemokines, we investigated the effect of such monocyte culture supernatants on migration of monocytes. The results revealed that the chemotactic activity of monocytes towards culture supernatants of lipopolysaccharides-stimulated monocytes was abrogated when incubated in the presence of $35 \mu \mathrm{g}$ of secretions/ml (Fig. 3a). Secretions did not induce migration of naive monocytes. Interestingly, secretions blocked migration of monocytes towards the chemotactic factor fMLP (Fig. 3b). Furthermore, the chemotactic response of monocytes towards combinations of monocyte culture supernatants and fMLP was decreased in the presence of secretions.

Effect of secretions on phagocytosis and intracellular killing of $S$. aureus by monocytes The results showed that secretions $(3.5$ and $35 \mu \mathrm{g} / \mathrm{ml}$ ) did not affect phagocytosis and intracellular killing of $S$. aureus $42 \mathrm{D}$ by monocytes (Table 2). The antibacterial functions of monocytes incubated with secretions for $18 \mathrm{~h}$ were identical to those of monocytes not incubated with secretions (data not shown).

Effect of secretions on cell surface receptors of monocytes The results (Table 3$)$ showed that secretions $(35 \mu \mathrm{g} / \mathrm{ml})$ did not means and SEM of six experiments. Each experiment was performed in quadruplicate. ${ }^{*} p<0.05$ for difference from monocytes stimulated without secretions. S, secretions

affect expression of the pathogen-recognition receptors CD282, CD284 and CD14 or that of the Fc $\gamma$ receptors CD16, CD32 and CD64, which are involved in the phagocytosis of opsonised bacteria, except for a reduction in lipopolysaccharides-induced expression of CD32 (FcRII). Additionally, expression of CD11b (together with CD18 complement receptor 3), which is involved in adhesion of monocytes to endothelial cells and phagocytosis of bacteria, was enhanced by secretions, while complement receptor 1 (CD35) expression was not affected. CD54 expression was enhanced by secretions on naive, but not on lipopolysaccharides-stimulated, cells.

Effect of secretions on the viability of monocytes The results showed that secretions dose-dependently enhanced the percentage of viable monocytes (Table 4). Moreover, the lipopolysaccharides-induced increase in monocytesurvival was further enhanced by secretions.

Effect of secretions on the intracellular cAMP concentration Analysis of the results revealed the peak cAMP concentration to be reached $15 \mathrm{~s}$ after addition of secretions $(35 \mu \mathrm{g} / \mathrm{ml})$, returning gradually to basal values at $120 \mathrm{~s}$ (data not shown). Based on these results, the $15 \mathrm{~s}$ interval was chosen to determine the dose-effect relation for secretions. The results revealed that $3.5 \mu \mathrm{g}$ of secretions/

Table 2 Effect of maggot secretions on phagocytosis and intracellular killing of Staphylococcus aureus by monocytes

\begin{tabular}{llllll}
\hline Secretions $(\mu \mathrm{g} / \mathrm{ml})$ & \multicolumn{2}{l}{$\begin{array}{l}\text { Phagocytosis }(\%) \text { at } \\
\text { indicated intervals }\end{array}$} & & \multicolumn{2}{l}{$\begin{array}{l}\text { Intracellular killing (\%) } \\
\text { at indicated intervals }\end{array}$} \\
\cline { 2 - 3 } \cline { 5 - 6 } & $30 \mathrm{~min}$ & $60 \mathrm{~min}$ & & $30 \mathrm{~min}$ & $60 \mathrm{~min}$ \\
\hline 0 & $12 \pm 3$ & $39 \pm 4$ & & $38 \pm 11$ & $61 \pm 7$ \\
3.5 & $21 \pm 4$ & $35 \pm 4$ & & $44 \pm 8$ & $55 \pm 10$ \\
35 & $19 \pm 2$ & $34 \pm 3$ & & $38 \pm 12$ & $57 \pm 10$ \\
\hline
\end{tabular}

Results are means \pm SEM of six experiments 
Table 3 Effect of maggot secretions on expression of surface molecules on monocytes

\begin{tabular}{lccccc}
\hline Surface molecule & \multicolumn{2}{l}{ No stimulus } & & \multicolumn{2}{l}{ Lipopolysaccharides $(100 \mathrm{ng} / \mathrm{ml})$} \\
\cline { 2 - 3 } \cline { 5 - 6 } & 0 & & & 0 & $\mathrm{~S}(35 \mu \mathrm{g} / \mathrm{ml})$ \\
\hline CD14 & $27 \pm 3$ & $26 \pm 3$ & & $68 \pm 12$ & $60 \pm 5$ \\
CD282 & $34 \pm 2$ & $34 \pm 2$ & & $14 \pm 2$ & $13 \pm 2$ \\
CD284 & $32 \pm 2$ & $29 \pm 2$ & & $22 \pm 5$ & $18 \pm 2$ \\
CD16 & $15 \pm 4$ & $12 \pm 2$ & & ND & ND \\
CD32 & $74 \pm 12$ & $78 \pm 18$ & & $273 \pm 27$ & $214 \pm 19^{*}$ \\
CD64 & $31 \pm 14$ & $35 \pm 18$ & & $8 \pm 1$ & $8 \pm 1$ \\
CD35 & $31 \pm 4$ & $28 \pm 3$ & & $29 \pm 3$ & $28 \pm 3$ \\
CD11b & $243 \pm 24$ & $399 \pm 52^{\dagger}$ & & $74 \pm 14$ & $122 \pm 21^{\dagger}$ \\
CD54 & $386 \pm 35$ & $517 \pm 54^{\dagger}$ & & $1,365 \pm 71$ & $1,293 \pm 60$ \\
\hline
\end{tabular}

$\mathrm{ml}$ significantly enhanced cAMP concentrations, with a maximum increase of 1.9-fold over basal level after exposure to $70 \mu \mathrm{g}$ of secretions $/ \mathrm{ml}$ (Table 5). In agreement with the above, the cAMP-dependent protein kinase A-inhibitor Rp-cAMPS (1 mmol/l) significantly attenuated the inhibitory effect of secretions $(35 \mu \mathrm{g} / \mathrm{ml})$ on the lipopolysaccharides-stimulated production of TNF- $\alpha$ (from $71 \pm 5$ to $41 \pm 12 \% ; n=9 ; p<0.005$ ) and of IL-12p40 (from $71 \pm 6$ to $32 \pm 14 \% ; \quad p<0.005)$, whereas it completely blocked $(p<0.05)$ the increase in IL-10 production by lipopolysaccharides-stimulated monocytes.

\section{Discussion}

The main conclusion from the present study is that maggot secretions suppress the pro-inflammatory responses of monocytes without affecting their antimicrobial activities. This conclusion is based on the following observations.

First, secretions reduced production of the proinflammatory cytokines IL-12p40, TNF- $\alpha$ and MIF by lipopolysaccharides-stimulated monocytes, whereas production of anti-inflammatory cytokine IL-10 was enhanced. Addition of secretions to monocytes that had already been exposed to lipopolysaccharides resulted in similar effects on the cytokine profile, indicating that secretions can interfere with an ongoing inflammatory reaction (data not shown). The anti-inflammatory actions of secretions are not limited to modulation of the TLR-4 pathway, as secretions exerted similar effects on cells stimulated with a TLR-2 ligand. Furthermore, secretions inhibited the lipopolysaccharidesinduced production of TNF- $\alpha$ and IL-12p40 by cells in whole blood (M. J. A. van der Plas and P. H. Nibbering, personal communication). However, production of the antiinflammatory cytokine IL-10 by blood cells was not affected by secretions, suggesting that the secretionsinduced increase in IL-10 production by purified monocytes may be counteracted by cellular/molecular components of whole blood. The suggestion that maggots produce IL-10 [19] can be ruled out as it was withdrawn by the authors (K. Y. Mumcuoglu, Department of Parasitology, Hebrew University-Hadassah Medical School, Jerusalem, Israel, personal communication).

Second, secretions decreased the chemotactic response of monocytes to fMLP as well as to the chemotactic factors in supernatant fractions of (lipopolysaccharides-stimulated) monocyte cultures. These results are in agreement with our earlier finding that excretions/secretions reduced the migration of human neutrophils towards fMLP [11]. The secretions-induced production of chemotactic factor MCP1 and decreased production of migration inhibitor MIF by monocytes did not increase migration, indicating that secretions inhibited migration independently of the levels of these chemokines; participation of MIP-1 $\beta$ inhibition cannot be ruled out. The effect of secretions-induced
Table 4 Effect of maggot secretions on the viability of monocytes

The results, expressed as the percentage of viable cells, are means \pm SEM of six to ten experiments

$* p<0.05,{ }^{\dagger} p<0.005$ for difference from control-incubated monocytes

\begin{tabular}{lcc}
\hline Lipopolysaccharides $(100 \mathrm{ng} / \mathrm{ml})$ & Secretions $(\mu \mathrm{g} / \mathrm{ml})$ & Survival (\%) \\
\hline No & 0 & $52 \pm 6$ \\
No & 0.35 & $54 \pm 7$ \\
No & 3.5 & $58 \pm 5^{*}$ \\
No & 35 & $74 \pm 4^{*}$ \\
No & 70 & $80 \pm 2^{*}$ \\
Yes & 0 & $69 \pm 4^{* \dagger}$ \\
Yes & 35 & $80 \pm 3^{*} \dagger$ \\
\hline
\end{tabular}


Table 5 Effect of maggot secretions on the cAMP concentration in monocytes

\begin{tabular}{ll}
\hline Secretions $(\mu \mathrm{g} / \mathrm{ml})$ & cAMP $(\mu \mathrm{mol} / \mathrm{l})$ \\
\hline 0 & $0.91 \pm 0.07$ \\
0.35 & $0.97 \pm 0.08$ \\
3.5 & $1.09 \pm 0.10^{*}$ \\
35 & $1.33 \pm 0.13^{*}$ \\
70 & $1.70 \pm 0.17^{*}$ \\
\hline
\end{tabular}

Results are means \pm SEM of ten experiments

${ }^{*} p<0.05$ for difference from control-incubated monocytes

increase of IL-8 and CD11b levels were not tested within our experimental setup. The increased expression of CD54 and $\mathrm{CD} 11 \mathrm{~b}$ on naive monocytes is unlikely to influence chemotaxis as monocytes are triggered when migrating into a wound.

Third, secretions did not affect the phagocytosis and intracellular killing of $S$. aureus by freshly isolated monocytes and by monocytes cultured for $18 \mathrm{~h}$. This is in agreement with our earlier findings that excretions/secretions had no effect on the phagocytosis and intracellular killing of Candida albicans by neutrophils [11]. Additionally, maggots aid in the removal of bacteria from wounds by ingesting bacteria together with liquefied necrotic tissue and subsequently killing them in their digestive tract [20, 21]. An important implication of the above observations that secretions interfered in a similar fashion with activation of TLR-2 and TLR-4 pathways is that the reported differences in effects of maggots on survival of grampositive and gram-negative bacteria [22] are likely to be the result of antibacterial activity [1] and not of differential modulation of immune cell responses.

Another major conclusion pertains to the mechanisms by which secretions exert their effects on monocytes. Our results showed that the effects of secretions on the cytokine/ chemokine profiles of lipopolysaccharides- and lipoteichoic acid-stimulated monocytes were not caused by an altered sensitivity to these stimuli. In agreement with this, secretions also had no effect on expression of surface molecules involved in the recognition of bacterial products by (lipopolysaccharides-stimulated) monocytes, suggesting that secretions exert their effects either downstream of these receptors or on other, as yet unidentified (intracellular) binding partners and targets. Based on our earlier finding that excretions/secretions increased intracellular cAMP levels in neutrophils [11], we assumed a similar mechanism by monocytes and, indeed, found that cAMP concentrations were dose- and time-dependently enhanced by secretions. Pre-treating monocytes with Rp-cAMPS, an inhibitor of cAMP-dependent protein kinase A-activation, attenuated the effects of secretions on lipopolysaccharides-stimulated cytokine production, indicating that maggots exert their effects on monocytes through a cAMP-dependent mechanism. Consistent with this, others have reported that activation of cAMP pathways is associated with reduced production of pro-inflammatory cytokines, including TNF$\alpha$, IL-12 and MIP-1 $\beta$, without affecting IL- $1 \beta$ production and while enhancing production of IL-10 [23, 24]. Furthermore, cAMP-elevation is connected to decreased migration $[25,26]$, whereas phagocytosis by freshly isolated monocytes remains unaffected [27]. However, elevation of cAMP was also associated with a moderate reduction in phagocytosis by incubated/stimulated monocytes and macrophages [27, 28], a finding that seems to be in contrast with our data. This discrepancy can be explained by our observation that secretions enhanced the viability of monocytes, such that although the total phagocytosis of bacteria remained the same, the amount of phagocytosis per viable monocyte decreased. As secretions did not decrease expression of FcR, CR1 or CD11b (part of CR3), the reduction in phagocytosis per cell may be explained by interference of signalling pathways downstream of receptor activation [28]. Interestingly, cAMP is known to inhibit apoptosis in several cell types [29-31].

What could be the clinical relevance of the present findings? Although pro-inflammatory responses are essential for healing of acute wounds, they can be detrimental in chronic wounds where inflammation persists. Some histological data suggest that parts of chronic wounds seem to be stuck in different phases of healing with loss of the synchronicity that leads to rapid healing [13]. Thus some part ready for epidermal resurfacing and fibroblast proliferation could be damaged by another part that is still in the inflammatory phase [32]. Chronic leg ulcers are associated with elevated levels of pro-inflammatory cytokines, like TNF- $\alpha$ and MIF, compared with acute wounds [33-35]. These cytokines enhance the production and release of a large variety of other pro-inflammatory cytokines [36, 37] as well as the synthesis of several matrix metalloproteinases and serine proteases $[15,37,38]$. When produced in excess these pro-inflammatory responses may cause deleterious extracellular matrix destruction [39-41], as well as growth factor and protease inhibitor inactivation [38, 42-44], and are responsible for the failure of wound healing. In addition, TNF- $\alpha$ activates phagocytes to produce reactive oxygen intermediates $[45,46]$, which can be toxic to cells like endothelial cells, fibroblasts and leucocytes, and may further promote tissue proteolysis by potentiating the effects of several proteinases, while inactivating proteinase inhibitors [47, 48]. Together, pro-inflammatory responses may be responsible for maintaining the chronic status of chronic wounds. Furthermore, TNF- $\alpha$ is also related to the formation of ulcers through its enhancement of plasminogen activator inhibitor-1 production [49, 50], which can 
lead to impaired lysis of pericapillary fibrin cuffs [51]. Importantly, although the mechanisms underlying the immunomodulatory effects of maggot secretions on monocytes are not fully elucidated, the findings from the present in vitro study show that maggot secretions potently inhibit the proinflammatory activities of monocytes. Secretions decrease migration of cells to the wound and reduce the amount of pro-inflammatory cytokines of the cells located in the wound, while their overall antibacterial activities are unaltered. Consequently, the release of other pro-inflammatory cytokines, reactive oxygen intermediates and proteases will diminish, bringing tissue destruction to a halt and possibly resulting in an environment beneficial for healing.

The exciting beneficial effect of maggots in treatment of diabetic foot ulcers and other chronic wounds, as found in clinical studies [6-9], could be explained by the phenomena described in this study. Apart from the direct antibacterial features of maggots observed in other studies [20,21] and our earlier observations that excretions/secretions can inhibit the formation and breakdown of bacterial biofilms [1], we found that maggots seem to preserve the important antibacterial function of human phagocytes, while protecting the fragile regenerating wound-bed against inflammation and tissue destruction by the same inflammatory cells.

Acknowledgements We thank S.J.P. Bogaards for technical assistance and E. J. G. Peters from the Department of Internal Medicine and Infectious Diseases, UMC, Utrecht, the Netherlands for critically reading the manuscript and for his valuable suggestions. This work was financially supported by a research grant of KCI Kinetic Concepts, Europe Holding (Amstelveen, the Netherlands).

Duality of interest The authors declare that there is no duality of interest associated with this manuscript.

Open Access This article is distributed under the terms of the Creative Commons Attribution Noncommercial License which permits any noncommercial use, distribution, and reproduction in any medium, provided the original author(s) and source are credited.

\section{References}

1. van der Plas MJA, Jukema GN, Wai SW et al (2008) Maggot excretions/secretions are differentially effective against biofilms of Staphylococcus aureus and Pseudomonas aeruginosa. J Antimicrob Chemother 61:117-122

2. Editorial (2005) Putting feet first in diabetes. Lancet 366:1674

3. Pecoraro RE, Reiber GE, Burgess EM (1990) Pathways to diabetic limb amputation. Basis for prevention. Diabetes Care 13:513-521

4. Boulton AJ, Vileikyte L, Ragnarson-Tennvall G, Apelqvist J (2005) The global burden of diabetic foot disease. Lancet 366:1719-1724

5. Peters EJ, Childs MR, Wunderlich RP, Harkless LB, Armstrong DG, Lavery LA (2001) Functional status of persons with diabetesrelated lower-extremity amputations. Diabetes Care 24:1799-1804
6. Mumcuoglu KY, Ingber A, Gilead L et al (1998) Maggot therapy for the treatment of diabetic foot ulcers. Diabetes Care 21:2030-2031

7. Sherman RA (2003) Maggot therapy for treating diabetic foot ulcers unresponsive to conventional therapy. Diabetes Care 26:446-451

8. Steenvoorde P, Jacobi CE, van Doorn L, Oskam J (2007) Maggot debridement therapy of infected ulcers: patient and wound factors influencing outcome - a study on 101 patients with 117 wounds. Ann R Coll Surg Engl 89:596-602

9. Armstrong DG, Salas P, Short B et al (2005) Maggot therapy in "lower-extremity hospice" wound care: fewer amputations and more antibiotic-free days. J Am Podiatr Med Assoc 95:254-257

10. Horobin AJ, Shakesheff KM, Pritchard DI (2006) Promotion of human dermal fibroblast migration, matrix remodelling and modification of fibroblast morphology within a novel 3D model by Lucilia sericata larval secretions. J Invest Dermatol 126:1410-1418

11. van der Plas MJA, van der Does AM, Baldry M et al (2007) Maggot excretions/secretions inhibit multiple neutrophil proinflammatory responses. Microbes Infect 9:507-514

12. Rosner K, Ross C, Karlsmark T, Petersen AA, Gottrup F, Vejlsgaard GL (1995) Immunohistochemical characterization of the cutaneous cellular infiltrate in different areas of chronic leg ulcers. APMIS 103:293-299

13. Loots MA, Lamme EN, Zeegelaar J, Mekkes JR, Bos JD, Middelkoop E (1998) Differences in cellular infiltrate and extracellular matrix of chronic diabetic and venous ulcers $v s$ acute wounds. J Invest Dermatol 111:850-857

14. Wetzler C, Kampfer H, Stallmeyer B, Pfeilschifter J, Frank S (2000) Large and sustained induction of chemokines during impaired wound healing in the genetically diabetic mouse: prolonged persistence of neutrophils and macrophages during the late phase of repair. J Invest Dermatol 115:245-253

15. Lobmann R, Schultz G, Lehnert H (2005) Proteases and the diabetic foot syndrome: mechanisms and therapeutic implications. Diabetes Care 28:461-471

16. Leijh PCJ, van der Barselaar M, Daha MR, van Furth R (1982) Stimulation of the intracellular killing of Staphylococcus aureus by monocytes: regulation by immunoglobulin $\mathrm{G}$ and complement components $\mathrm{C} 3 / \mathrm{C} 3 \mathrm{~b}$ and $\mathrm{B} / \mathrm{Bb}$. J Immunol 129:332-337

17. Koopman G, Reutelingsperger CP, Kuijten GA, Keehnen RM, Pals ST, van Oers MH (1994) Annexin V for flow cytometric detection of phosphatidylserine expression on B cells undergoing apoptosis. Blood 84:1415-1420

18. Nibbering PH, Zomerdijk TP, Corsel-Van Tilburg AJ, van Furth R (1990) Mean cell volume of human blood leucocytes and resident and activated murine macrophages. J Immunol Methods 129:143145

19. Mumcuoglu KY (2001) Clinical applications for maggots in wound care. Am J Clin Dermatol 2:219-227

20. Mumcuoglu KY, Miller J, Mumcuoglu M, Friger M, Tarshis M (2001) Destruction of bacteria in the digestive tract of the maggot of Lucilia sericata (Diptera: Calliphoridae). J Med Entomol 38:161-166

21. Robinson W, Norwood VH (1933) The role of surgical maggots in the disinfection of osteomyelitis and other infected wounds. J Bone Jt Surg Am 15:409-412

22. Steenvoorde P, Jukema GN (2004) The antimicrobial activity of maggots: in-vivo results. J Tissue Viab 14:97-101

23. Eigler A, Siegmund B, Emmerich U, Baumann KH, Hartmann G, Endres S (1998) Anti-inflammatory activities of cAMP-elevating agents: enhancement of IL-10 synthesis and concurrent suppression of TNF production. J Leukoc Biol 63:101-107

24. Zidek Z (1999) Adenosine-cyclic AMP pathways and cytokine expression. Eur Cytokine Netw 10:319-328

25. Fine JS, Byrnes HD, Zavodny PJ, Hipkin RW (2001) Evaluation of signal transduction pathways in chemoattractant-induced human monocyte chemotaxis. Inflammation 25:61-67 
26. Kaneko T, Alvarez R, Ueki IF, Nadel JA (1995) Elevated intracellular cyclic AMP inhibits chemotaxis in human eosinophils. Cell Signal 7:527-534

27. Bryn T, Mahic M, Enserink JM, Schwede F, Aandahl EM, Tasken $\mathrm{K}$ (2006) The cyclic AMP-Epac1-Rap1 pathway is dissociated from regulation of effector functions in monocytes but acquires immunoregulatory function in mature macrophages. J Immunol 176:7361-7370

28. Serezani CH, Ballinger MN, Aronoff DM, Peters-Golden M (2008) Cyclic AMP: master regulator of innate immune cell function. Am J Respir Cell Mol Biol 39:127-132

29. Soga F, Katoh N, Kishimoto S (2007) Histamine prevents apoptosis in human monocytes. Clin Exp Allergy 37:323-330

30. Ottonello L, Gonella R, Dapino P, Sacchetti C, Dallegri F (1998) Prostaglandin E2 inhibits apoptosis in human neutrophilic polymorphonuclear leukocytes: role of intracellular cyclic AMP levels. Exp Hematol 26:895-902

31. Passeron T, Namiki T, Passeron HJ, Le Pape E, Hearing VJ (2009) Forskolin protects keratinocytes from UVB-induced apoptosis and increases DNA repair independent of its effects on melanogenesis. J Invest Dermatol 129:162-166

32. Falanga V (2005) Wound healing and its impairment in the diabetic foot. Lancet 366:1736-1743

33. Goren I, Kampfer H, Podda M, Pfeilschifter J, Frank S (2003) Leptin and wound inflammation in diabetic ob/ob mice: differential regulation of neutrophil and macrophage influx and a potential role for the scab as a sink for inflammatory cells and mediators. Diabetes 52:2821-2832

34. Trengove NJ, Bielefeldt-Ohmann H, Stacey MC (2000) Mitogenic activity and cytokine levels in non-healing and healing chronic leg ulcers. Wound Repair Regen 8:13-25

35. Yabunaka N, Nishihira J, Mizue Y et al (2000) Elevated serum content of macrophage migration inhibitory factor in patients with type 2 diabetes. Diabetes Care 23:256-258

36. Hirano Y, Shichijo M, Deguchi M et al (2007) Synergistic effect of PGD2 via prostanoid DP receptor on TNF-alpha-induced production of MCP-1 and IL-8 in human monocytic THP-1 cells. Eur J Pharmacol 560:81-88

37. Calandra T, Roger T (2003) Macrophage migration inhibitory factor: a regulator of innate immunity. Nat Rev Immunol 3:791-800

38. Agren MS, Werthen M (2007) The extracellular matrix in wound healing: a closer look at therapeutics for chronic wounds. Int $\mathrm{J}$ Low Extrem Wounds 6:82-97
39. Lobmann R, Ambrosch A, Schultz G, Waldmann K, Schiweck S, Lehnert H (2002) Expression of matrix-metalloproteinases and their inhibitors in the wounds of diabetic and non-diabetic patients. Diabetologia 45:1011-1016

40. Briggaman RA, Schechter NM, Fraki J, Lazarus GS (1984) Degradation of the epidermal-dermal junction by proteolytic enzymes from human skin and human polymorphonuclear leukocytes. J Exp Med 160:1027-1042

41. Herrick S, Ashcroft G, Ireland G, Horan M, McCollum C, Ferguson M (1997) Up-regulation of elastase in acute wounds of healthy aged humans and chronic venous leg ulcers are associated with matrix degradation. Lab Invest 77:281-288

42. Chen SM, Ward SI, Olutoye OO, Diegelmann RF, Kelman CI (1997) Ability of chronic wound fluids to degrade peptide growth factors is associated with increased levels of elastase activity and diminished levels of proteinase inhibitors. Wound Repair Regen 5:23-32

43. Lauer G, Sollberg S, Cole M et al (2000) Expression and proteolysis of vascular endothelial growth factor is increased in chronic wounds. J Invest Dermatol 115:12-18

44. Trengove NJ, Stacey MC, MacAuley S et al (1999) Analysis of the acute and chronic wound environments: the role of proteases and their inhibitors. Wound Repair Regen 7:442-452

45. Gauss KA, Nelson-Overton LK, Siemsen DW, Gao Y, DeLeo FR, Quinn MT (2007) Role of NF-kappaB in transcriptional regulation of the phagocyte NADPH oxidase by tumor necrosis factor-alpha. J Leukoc Biol 82:729-741

46. Meier B (2001) Superoxide generation of phagocytes and nonphagocytic cells. Protoplasma 217:117-124

47. Chen WY, Rogers AA (2007) Recent insights into the causes of chronic leg ulceration in venous diseases and implications on other types of chronic wounds. Wound Repair Regen 15:434-449

48. Wlaschek M, Scharffetter-Kochanek K (2005) Oxidative stress in chronic venous leg ulcers. Wound Repair Regen 13:452-461

49. Skurk T, Hauner H (2004) Obesity and impaired fibrinolysis: role of adipose production of plasminogen activator inhibitor-1. Int $\mathrm{J}$ Obes Relat Metab Disord 28:1357-1364

50. Lopez S, Peiretti F, Bonardo B, Juhan-Vague I, Nalbone G (2000) Tumor necrosis factor alpha up-regulates in an autocrine manner the synthesis of plasminogen activator inhibitor type-1 during induction of monocytic differentiation of human HL-60 leukemia cells. J Biol Chem 275:3081-3087

51. Agirbasli M (2005) Pivotal role of plasminogen-activator inhibitor 1 in vascular disease. Int J Clin Pract 59:102-106 